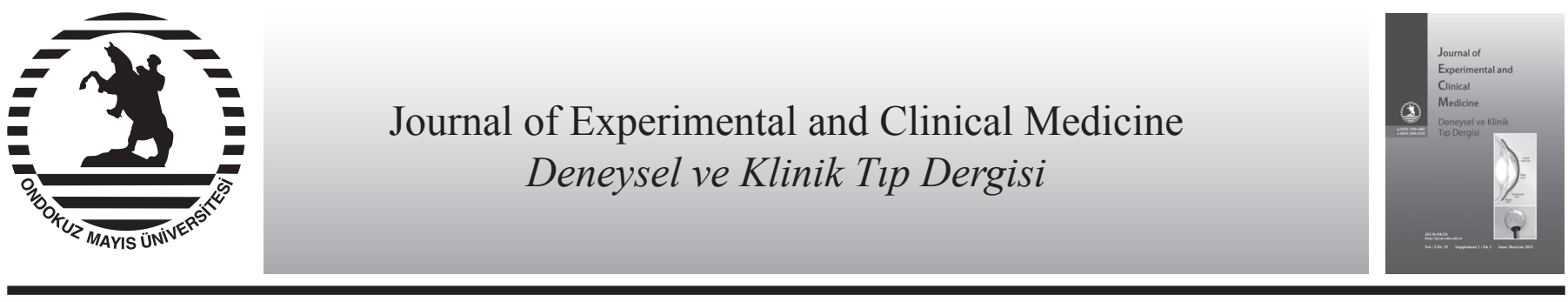

Derleme / Review

doi: $10.5835 /$ jecm.omu.29.s2.003

\title{
Kuru göz tedavisinde güncel tedavi yöntemleri
}

\section{Current treatment methods of dry eye syndrome}

\author{
Sezin Akça Bayar*, Yonca A. Akova \\ Başkent Üniversitesi Hastanesi, Göz Hastalıkları Anabilim Dalı, Ankara, Türkiye
}

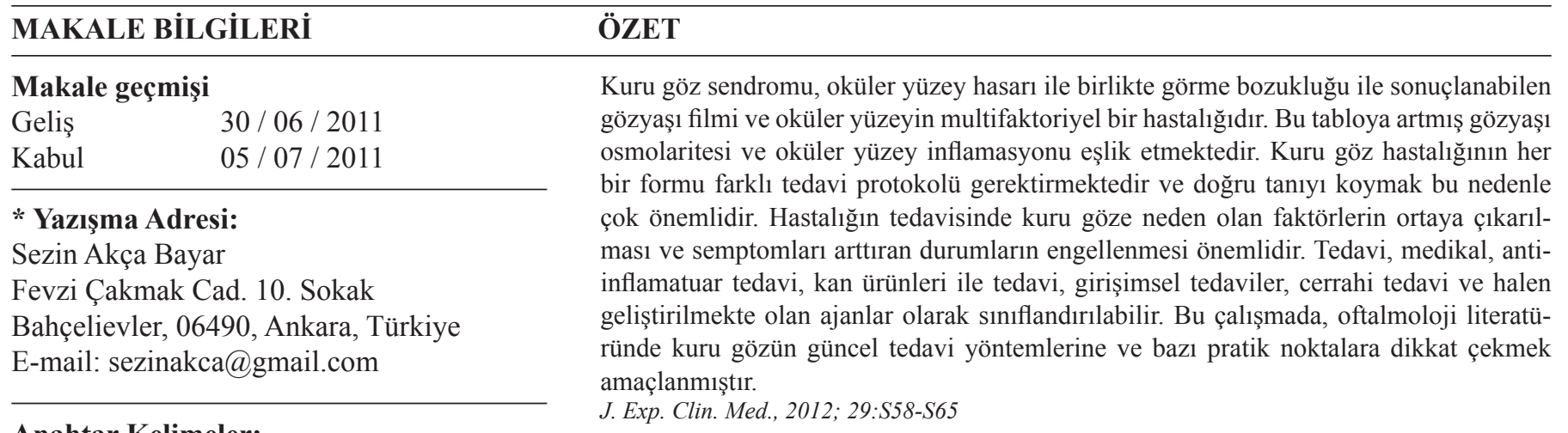

Anahtar Kelimeler:

Kuru göz sendromu

Tedavi

Anti-inflamatuar ilaçlar

Otolog serum

Cerrahi prosedürler

Yeni ilaçlar

\section{Keywords:}

Dry eye syndrome

Treatment

Anti-inflammatory drugs

Autologous serum

Surgical procedures

New agents

\begin{abstract}
Dry eye syndrome is a multifactorial disorder of the tear film and ocular surface that results in symptoms of visual disturbances and tear film instability with potential damage to the ocular surface. It's accompanied by increased osmolarity of the tear film and inflammation of the ocular surface. Each form of dry eye requires different therapeutic approaches and therefore it is essential to establish the exact diagnosis. The treatment of dry eye consists of finding the underlying cause and avoiding the conditions that may aggravate the symptoms of dry eye. Treatment may be classified as medical treatment, anti-inflammatory therapy, blood products, invasive treatment strategies, surgical treatment, and new therapeutic agents that currently being studied. Here, we aimed to review the evolution of the new treatment strategies of dry eye in ophthalmic literature and emphasize some practical points.

J. Exp. Clin. Med., 2012; 29: S58-S65
\end{abstract}

\section{Kuru göz sendromunda güncel tedavi yöntemleri}

Kuru göz sendromuna (KGS) neden olan faktörlerin ortaya çıkarılması kuru göz tedavisinde çok önemlidir ve ilk basamaktır. Kuru göz hastalarında gerek altta yatan nedenlere, gerek hastalığın kendisine ve gerekse komplikasyonlara yönelik tedaviler esas tedavi yöntemlerini oluşturmaktadır. 2007'de "International Dry Eye Workshop (DEWS)" grubunun tanımladığı şekilde kuru göz aslında "Oküler yüzey hasarı ile birlikte rahatsızlık hissi, görme bozukluğu ve stabil olmayan gözyaşı film tabakasına neden olan gözyaşı ve oküler yüzeyin multifaktoriyel disfonksiyonu" olarak belirtilmiştir. Bu nedenle etyolojiye baktığımızda aslında birçok farklı mekanizmanın rol oynadığını görmekte ve tedavi planlarken de bu mekanizmalar göz önünde bulundurulmaktadır. Uzun yıllardır devam eden araştırmalara rağmen kuru göz tanısı ve tedavisi halen zorluk taşımaktadır. Tanıda semptomların ayrıntılı değerlendirilmesi ve tanısal testlerin uygun kombinasyonları ile hastaya yaklaşılması çok önemlidir. Tedavinin başarısını, konulan tanının doğruluğu ve olguların kuru göz etyopatogenezine göre uygun sinıflandırılması belirlemektedir (Akova ve ark., 2008).

İlk tedavi kılavuzu 2003 yılında American Academy of Ophthalmology tarafından hazırlanmıştır ve etyolojiye yönelik bir sınıflandırma ve tedavi önerilmiştir. "International Task Force" tarafından hazırlanan ve Delphi yaklaşımı da denilen 2006'da basılan kılavuz ise klinik bulguların şiddetine göre sinıflandırma yapmaktadır (Behrens ve ark., 2006). 2007'de ise DEWS, bu kılavuzda değişiklikler yaparak gözyaşı k1rılma zamanı ve Schirmer testi sonuçlarının da kuru gözün şiddetinin saptanmasında kullanılmasını önermişlerdir. Tablo 
1'de bu kılavuzda kuru gözün şiddetine göre aşamalı tedavi yaklaşımı görülmektedir.

Tedavi yaklaşımı genel olarak koruyucu yöntemler, medikal tedavi (topikal lubrikanlar ve antiinflamatuarlar/immunmodülatörler, kan ürünü gözyaşı takviyeleri), girişimsel yöntemler ve cerrahi tedavi olarak sinıflandırabilir. Ek olarak geleceğe yönelik güncel tedavi yaklaşımlarından da bahsedilecektir.

\section{Genel ve koruyucu önlemler}

- Göz kırpma sayısının arttırılması: Çalıșma ortamı nedeniyle veya ekstrapiramidal sistem hastalıkları (Parkinson hastalığı) olan kişilerde gözlerini sıkıca kapatıp açmaları lipid salınımını stimüle ederek gözyaşı buharlaşmasını arttıracaktır.

-Ortamdaki nemin arttırılması: Cihazlar ile ortam nemi arttırılabilir.

-Ortam 1sısının ayarlanması: Kenarı kapalı olan gözlükler ile ortam 1sıs1 ve nemi arttırılabilir.

-Ortamdaki hava sirkülasyonunun değiştirilmesi.

-Ortam 1şıklandırması: Floresan ışık ve yoğun güneşli ortam semptomları arttırmaktadır.

-Çalışma ortamında ekran ile ilişkinin düzenlenmesi: Bilgisayar ekranı 10-15 derece aşağıda olacak şekilde ayarlanmalıdir (Sheedy ve ark., 2003).

-Ortamdaki sigara dumanının ve tozun azaltılması (Altınörs ve ark., 2006).

-Kafein ve alkol alımının düzenlenmesi: Sempatikparasempatik sistem uyarının değişmesi sonucu gözyaşı etkilenmektedir.

-Sıv1 alımının arttırılması.

-Gözyaşına etkili sistemik ve lokal ilaçların alımına yönelik uyarı ve tedbirler ( $\beta$-Blokör, antihistaminikler, antihipertansifler, antiandrojenler, östrojen gibi).

-Sicak kompres uygulaması: Meibomian fonksiyonları düzenlenmiş olur (Craig ve ark., 1997).

-Buhar tedavisi: Bu amaçla kullanılan gözlükler mevcuttur.

\section{Medikal tedavi}

\section{1.a. Suni gözyaşı preparatları}

Lakrimal fonksiyonel üniteyi oluşturan oküler yüzey, ana lakrimal bez, kırpma refleksi ve bu yapıları birbirine bağlayan duyusal ve motor sinirler karşılıklı işbirliği içerisindedir (Stern ve ark., 2004). Kuru göz hastalığının esas tedavisi eksik olanın yerine konulması ve lakrimal fonksiyonel ünitenin reorganizasyonu şeklinde özetlenebilir. Tedavi "International Task Force Guidelines for Dry Eye" kılavuzuna göre yap1lmaktadır (Wilson ve ark., 2007). Buna göre kuru göz 4 evreye ayrilarak incelenmektedir ve her evrede ortak olarak suni gözyaşı preparatları tercih edilmektedir. Yaygın olarak kullanılan suni gözyaşı preparatları $\mathrm{pH}$, osmotik basınç, yüzey gerilimi, viskozite, buharlaşma ve prezervan içeriklerine göre farklılık göstermektedir.

Tablo 2'de gösterildiği gibi suni gözyaşı preparatlarının kimyasal içerikleri şunlardır

-Tuz çözeltileri: Sodyum klorid, potasyum klorid, kalsiyum klorid, magnezyum klorid, sodyum bikarbonat, sodyum fosfat, sodyum tiyofosfat, sodyum borat, borik asit, hidroklorik asit, sodyum hidroksit. Tuz çözeltisinin miktarına göre damlanın osmolaritesi değişir. Gözyaşı kuru göz hastalığında hiperosmolar olduğundan damlalar izoosmolar veya hipoosmo- lar olmaktadır (Murube ve ark.,1998).

-Gliserol, monosakkaridler, disakkaridler.

-Polisakkaridler:

Sakızlar: En çok kullanılan selüloz türevleridir (Hidroksipropil metilselüloz ve karboksipropil metiselüloz).

Dekstranlar: Dekstran 85, 70, 60 veya 40.

Mukopolisakkaridler: Son y1llarda kullanıma girmiştir. Oküler yüzey epitelini iyileştirici etkisi vardır.

- Sentetik polimerler: Vinil deriveleri (polivinil alkol, povidon, poliakrilik asit) ve etilen glikol (polietilen glikol) deriveleri.

- Jelatinler.

- Lipidler: parafin, vazelin, mineral yağı ve lanolin.

Koruyucu ajanlar (Prezervanlar)

Geleneksel olarak tiomersal, klorobutanol sorbat ve benzalkolyum klorid kullanılmaktadır. Oksidatif prezervanlar olan stabilize oksikloro kompleksi (SOC) ve sodyum perborat diğer maddelerdir. Son y1llarda diğer bir prezervan sistem ise gümüş iyonları ile kaplanmış bir küreciğin suni gözyaŞ1 damlalığının içine yerleştirilmesi ile geliştirilmiştir. Hava ile temas gümüş iyonlarını aktive ederek antibakteriyel etki oluşturmaktadır.

Elektrolitler

En sik bikarbonat ve potasyum bulunmaktadır ve kornea epitel metebolizmasında rol oynamaktadirlar.

Osmolorite

Doğal gözyaşında bulunan ve osmolariteyi sağlayan en önemli elektrolit $\mathrm{NaCl}$ 'dir. Gözyaşı preparatlarının bir kısmı izoosmolar, bir kısmı ise hipoosmolardır (Murube ve ark.,1998). $p H$

Kuru göz hastalarında gözyaşı pH'sı daha yüksektir. Gözyaşı filmindeki bikarbonat havadaki karbondioksit ile birleşerek oküler yüzeydeki alkali ortamı tamponlamaktadır.

\section{1.b. Antiinflamatuarlar ve immunmodülatörler}

Kuru göz patogenezinde inflamasyonun öneminin farkedilmesi ile yeni tedavi yaklaşımları gündeme gelmiştir. 1998'de Stern ve arkadaşlarının ileri sürdüğü gözyaşı fonksiyonel ünitesi kuru göz patogenezindeki inflamasyon modelini destekler niteliktedir (Stern ve ark., 1998). Hiperosmolar gözyaşı inflamatuar medyatörlerin salınımı ve inflamatuar kaskadın aktive olması ile yüzey epitelini hasara uğratabilir ve goblet hücre kaybı ile müsin üretiminde azalmaya neden olabilir (Djalilian ve ark., 2005).

Suni gözyaşı preparatına rağmen konjonktivadaki hipereminin, korneadaki boyanmanın ve iritasyon şikayetlerinin devam ettiği olgular antiinflamatuar tedavi için adaydırlar.

\section{Topikal kortikosteroid}

Kuru gözde hem kuruluğun hem de hiperosmolaritenin kornea ve konjonktiva epiteli üzerine yaptığı stres bu hücrelerden inflamatuar sitokinlerin (IL-1, 6, 8, TNF $\alpha$, TNF $\beta$ ), MMP-9, ICAM ve konjonktivada T lenfositlerinin artışına yol açmaktadır (Pflugfelder ve ark., 1999). Oküler yüzeydeki inflamasyonu baskılamaya yönelik tedavi seçenekleri arasında kortikosteroidler ilk sırayı almaktadır. Ancak kronik kullanımlarında ciddi yan etkilerinin olabilmesi nedeni ile kısa süreli tedaviler önerilmektedir. Tercihan prezervan içermeyen kortikosteroidler günde 3-4 defa 2 ile 4 hafta süre ile uygulanır. Eğer daha uzun süre uygulama gerekirse fluorometalon, hidroksimetilprogestaron veya loteprednol etabonate içeren 
preparatlar göziçi basıncını arttırma etkileri daha zayıf olmaları sebebiyle tercih edilmelidir.

\section{Tetrasiklinler}

Tetrasiklinlerin antibiyotik olarak etkilerinin yanısıra antiinflamatuar olarak da etkilerinin olduğu gösterilmiştir.Tetrasiklin ve türevleri MMP'nin etkisinin yoğun olduğu oküler rozasea, blefarit, meibomit gibi oküler yüzey hastalıklarının tedavisinde kullanılmaktadır (Frucht-Pery ve ark., 1989; Yoo ve ark., 2005). Stres altındaki kornea epiteli mitojen aktivasyonlu protein kinaz (MAPK) aktivasyonuna neden olmaktadir. MAPK da bir dizi inflamatuar sitokinin (IL-1 $\alpha$, IL-1 $\beta$, IL-8, TNF $\alpha$ ) ve MMP-1,3,9,10,13'ün açığa çıkmasını uyarmaktadır. Tetrasiklinler MAPK aktivasyonunu engelleyerek MMP salınımını önler (De Paiva ve ark., 2006). Doksisiklin ve minosiklin, doku konsantrasyonlarının daha yüksek olmas1 ve serum proteinlerine daha yüksek oranda bağlanmaları nedeniyle uzun süreli kullanımlarda tercih edilmektedir. yan meibum içindeki serbest yağ asitlerinin polar lipidlere dönüştürülmesinden kaynaklanan inflamasyonu, bakteri kolonizasyonunun ürettiği bakteri lipazlarını da baskılamaktadir (Perry ve ark., 2006).

Topikal Cs A'nın şikayet ve bulgulara olumlu etkisi geç ortaya çıkmaktadır. Bu süre 8. haftaya ve maksimum etkisinin ortaya çıkması 6 . aya kadar uzayabilmektedir. O nedenle tedaviyi mutlak kontrendikasyon olmadikça en az 6 aya tamamlamak ve ihtiyaç duyulduğunda belki 1 yıl aralıklarla tekrar etmek gerekebilmektedir.

Çok merkezli faz II çalışmada \%0,05, 0,1, 0,2 ve 0,4'lük Cs A uygulamasında doza bağlı olmaksızın 12 haftalık tedavi süresince korneal boyanma skorlarında ve kuru göz şikayetlerinde suni gözyaşı grubuna göre anlamlı düzelme saptanmıştır (Stevenson ve ark., 2000). Yine 6 aylık \%0,05 ve 0,1'lik Cs A uygulanan faz III çalışmasında doza bağlı olmazsızın bulgularda ve test sonuçlarında belirgin düzelme saptanmıştır (Sall ve ark., 2000).

\section{Tablo 1. Kuru gözde hastalığın ciddiyetine göre evrelendirme ve tedavi klavuzu şeması (Delphi tarafından oluşturulan ve $D E W S^{1}$} tarafindan kabul edilen evreleme sistemi)

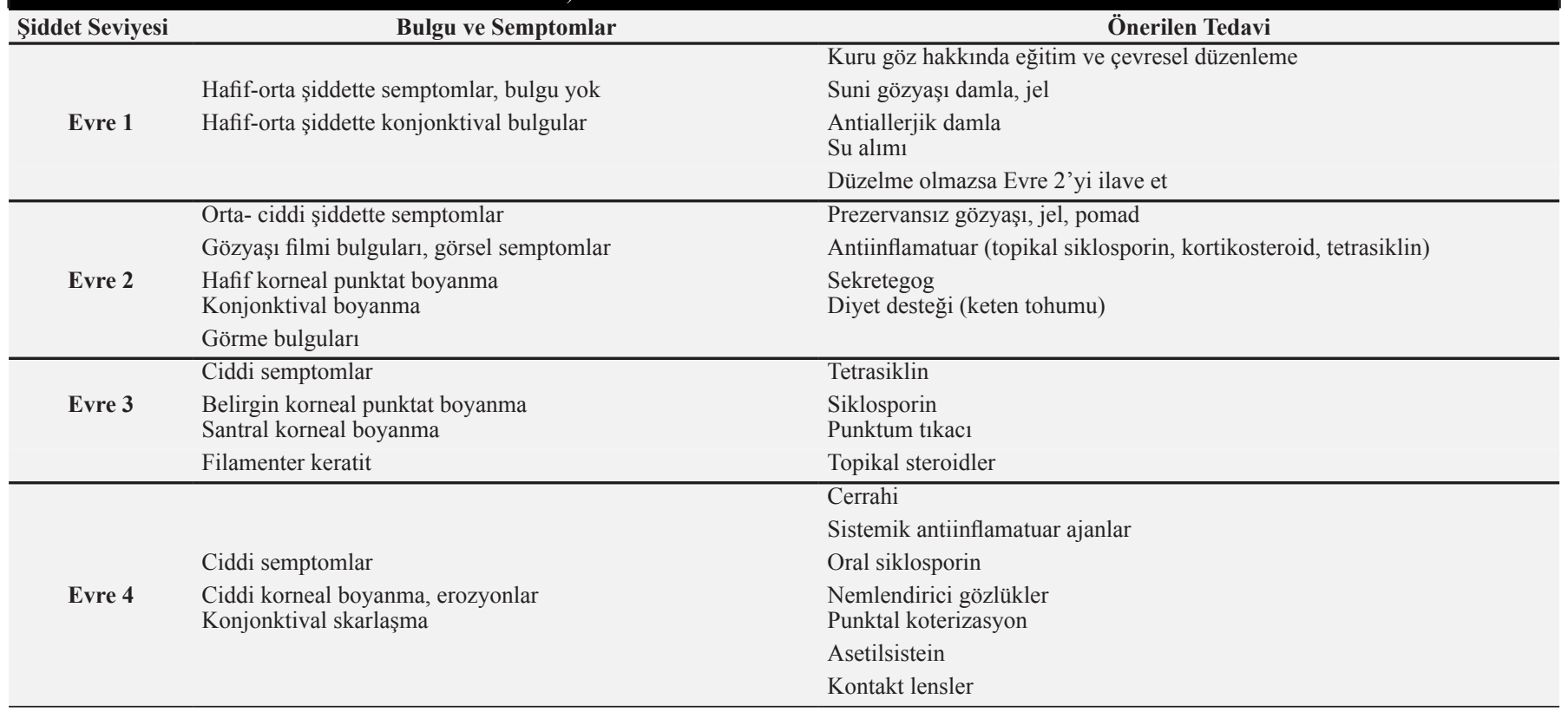

Topikal siklosporin A (Cs A)

Siklosporinin en belirgin 2 etkisi T lenfosit aktivasyonunu baskılamak ve çeşitli hücre tiplerinde apoptozisi önlemektir. Bu etkileri sitoplazmada bulunan siklofilin A ve D denilen iki sitoplazmik protein yardımı ile oluşturmaktadır. Siklofilin A ile Cs A'nın birleşmesi ile T lenfosit aktivasyonu sırasında özellikle IL-2 salınımı önlenmiş olur ve hücresel bağışıklık cevabı baskılanır. Siklofilin D'nin Cs A ile birleșmesi sonucu hücrede apoptozis baskılanır. Cs A'nın konjonktiva epitelinde apoptozisi azalttığı farelerdeki kuru göz modelinde gösterilmiştir (Strong ve ark., 2005). Yapılan çok merkezli 877 olguyu içeren bir Faz III çalışmasında \%0,05 ve \%0, 1 'lik Cs A kullanımı karşılaştırılmış ve 6 aylık tedavi sonrasında her iki doz grubunda belirgin olarak gözyaşı fonksiyonlarında ve subjektif şikayetlerde düzelme olmuştur (Sall ve ark., 2000). Bir başka çalışmada da aköz yetmezlik ile birlikte olan kuru göz olgularında topikal Cs A uygulamasının azalmış goblet hücre sayısında ve bu hücrelerden salgılanan TGF'de artışa neden olduğu saptanmıştır (Pflugfelder ve ark., 2008). Topikal siklosporin A kuru gözün yarattığı inflamasyonu baskılamanın yanısıra meibomian bezlerinin salgı kanallarını tıka-

\section{1.c. Kan ürünü gözyaşı takviyeleri}

Yapay gözyaşı preparatları oküler yüzeyin kayganlaşt1rılması, osmolaritenin düşürülmesi, oküler yüzeydeki inflamatuar debrislerin yıkanarak veya dilüe edilerek uzaklaştırılması açısından işlev görseler de, trofik ajan, anti-inflamatuar bileşen, immun savunma aracı içermedikleri için her zaman yeterli olmazlar (Geerling ve ark., 2006).

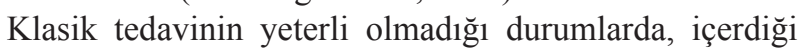
bileşenler açısından gözyaşına çok benzer olan kan ürünleri önemli bir tedavi seçeneği olarak gündeme gelmektedir. Gözyaşı takviyesinde kullanılan kan ürünleri, serum, plazma, trombosit konsantreleri, albumin ve kordon kanı olarak say1labilir.

\section{Otolog serum}

Oküler yüzey hastalıklarında en sık kullanılan üründür (Utine ve ark., 2010; Yağc1, 2010). Osmolarite ve pH yönünden gözyaşına oldukça benzeyen serumun büyüme faktörleri yönünden konsantrasyonu gözyaşına göre oldukça yüksektir. En ideal hazırlama protokolü konusu, Liuve ve Haermingshaus'un yaptığı in-vitro çalışmalar ile şu şekilde 
Tablo 2. Suni gözyaşı preparatları

\begin{tabular}{|c|c|c|c|}
\hline Ticari Ad & Firma Adı & Etken madde & Koruyucu madde \\
\hline \multicolumn{4}{|l|}{ Damlalar } \\
\hline \multirow[t]{3}{*}{ Tears Naturale ${ }^{\circledR}$ II } & Alcon & Dextran 70, hidroksipropil metilsellüloz & Poliquaternium-1, $0.001 \%$ \\
\hline & & Sodyum borat, Potasyum klorid, Sodyum klorid & \\
\hline & & Saflastirilmis su, hidroklorik asid-sodyum hidroksid & \\
\hline \multirow[t]{3}{*}{ Tear Naturale ${ }^{\mathrm{TM}}$ Free } & Alcon & Dextran 70, hidroksipropil metilsellüloz & Poliquaternium-1, $0.001 \%$ \\
\hline & & Sodyum borat, Potasyum klorid, Sodyum klorid & \\
\hline & & Saflaştırılmış su, hidroklorik asid-sodyum hidroksid & \\
\hline \multirow[t]{2}{*}{ Liquifilm Tears ${ }^{\circledR}$} & Abdi İbrahim & Polivinil alkol & Klorobutanol $0.5 \%$ \\
\hline & & Saflaştırılmış su, Sodyum klorür & \\
\hline \multirow[t]{2}{*}{ Dacrolux ${ }^{\circledR}$} & Alcon & Dekstran 70, hidroksipropilmetilsellüloz & Benzalkonyum klorür \\
\hline & & Monosodyum-disodyumfosfat & \\
\hline \multirow[t]{2}{*}{ Protagent } & Liba & Polivinilpirolidon (\% 2) & Benzalkonyum klorür \\
\hline & & Borik asid & \\
\hline Protagent SE & Liba & Polivinilpirolidon ( $0.02 \mathrm{~g}$ ) & Yok \\
\hline \multirow[t]{2}{*}{ Oculotect Fluid ${ }^{\circledR}$} & Novartis & Polivinilpirolidon (50mg) & Benzalkonyum klorür \\
\hline & & Borik asid, Sodyum klorür, Potasyum klorür & \\
\hline \multirow[t]{2}{*}{ Oculotect Fluid® SE } & Novartis & Polivinilpirolidon (50mg) & \\
\hline & & Borik asid, Sodyum klorür, Potasyum klorür & Yok \\
\hline \multirow[t]{2}{*}{ Clarex } & Abdi İbrahim & Etedik asit & Klorheksidin \\
\hline & & 1-glutamik asit, 1-arginin & \\
\hline Brunac & Biocer & $\% 5 \mathrm{~N}$-Asetilsistein & \\
\hline Refresh & Allergan & Polivinil alkol, povidon, sodyum klorür & Yok \\
\hline Genteal & Novartis & Hidroksipropil metilselüloz $\% 0.3$ & Sodyum perborat \\
\hline Artelac & Bausch\& Lomb & Hidroksipropil metilselüloz & Yok \\
\hline Refresh tears & Allergan & Karboksimetilselüloz $\% 0.5$ & Oksikloro kompleksi (Purite) \\
\hline Systane & Alcon & Propilen glikol \%0.3 & Polikauternium \\
\hline Eyestil & Teka & Sodyum hyalüronat $\% 0.15$ & Benzalkonyum klorür \\
\hline Hylo Lasop & Ursapharm & Sodyum hyalüronat $1 \mathrm{mg} / \mathrm{ml}$ & Yok \\
\hline \multicolumn{4}{|l|}{ Pomadlar } \\
\hline Lacryvisc & Alcon & Karbomer, mannitol & Tiomersal \\
\hline Viscotears ${ }^{\circledR}$ & Novartis & Poliakrilik asit, disodyum edetat, sorbitol & Setrimid \\
\hline Thilo-Tears & Liba & Karbomer, mannitol & Tiomersal \\
\hline Duratears & Liba & Mineral yağ, susuz sıvı lanolin, beyaz vazelin & Metilparaben \\
\hline Refresh liquigel & Allergan & Karboksimetil selüloz \%1 & Oksikloro kompleksi (Purite) \\
\hline Siccapos & Biem & Karbopol 980 2mg & Setrimid \\
\hline
\end{tabular}

belirlenmiştir (Herminghaus ve ark. 2004; Liu ve ark., 2005)..

Pıhtılaşma fazı: En çok uygulanan yöntem hem işleyişin daha pratik olması hem de aynı gün hastaya teslim avantaj1 nedeniyle 2 saatlik (oda sicaklığında, $18-25^{\circ} \mathrm{C}$ ) bir bekleme süresidir. Ancak ne kadar beklenirse o kadar fazla büyüme faktörü elde edilmektedir.

Santrifüj fazl: Klinik uygulamarda Tsubota ve ark. (1999)'nın önerisi ile 5 dk süre ile 1500 devir/dk olan yaklaşım dikkate alınmaktadır. Çökeltinin üzerindeki serum, laminar hava akım davlumbazında steril koşullar altında uzaklaştirilir.

Sulandırma fazı: İçeriği doğal gözyaşından daha fazla olan serum genellikle sulandırılarak kullanılmaktadır. Serum \%20 dengeli tuz çözeltisi ile yarı yarıya seyreltilir. Seyreltilmiş serum steril olarak filtrelenir $(0,2 \mu \mathrm{m}$ delik büyüklüğünde) ve tek kullanımlık damlalıklara paylaştırılır.

Saklama fazı: İdeali hergün yeniden hazırlanmasıdır ancak, klinik pratikte çok mümkün olmamasından dolayı genellikle günlük dozlar halinde derin dondurucuda saklanıp kullanılması önerilmektedir. $+4^{\circ} \mathrm{C}$ 'de 1 ay; $-20^{\circ} \mathrm{C}$ 'de 3 aya kadar saklanabilmektedir. Bu süre içerisinde fibronektin, epidermal büyüme faktörü, dönüştürücü büyüme faktörü gibi büyüme ve yara iyileşmesi faktörlerinin etkisinin devam ettiği düşünülmektedir (Geerling ve ark., 2008). Kuru göz tedavisinde kişinin kendi serumunun kullanılması ilk kez Fox tarafindan 1984 y1lında bildirilmesi ile birlikte 1999'da Tsubota ve ark.'nın çalışması ile devam etmiştir (Fox ve ark., 1984; Tsubota ve ark., 1999). Bu iki çalışmada da kuru göz bulgularında değişik oranlarda düzelme saptanmıştır. Günümüze kadar yapılan diğer çalışmalar dikkate alındığında klinik protokollerde ve hasta gruplarındaki farklılıklara bağlı olarak klinik düzelmede \%33 ile 100 arasında çok geniş bir spektrum izlenmektedir (Tsubota ve ark., 1999; Tananuvat ve ark., 2001; Watson ve ark., 2010; Lee ve ark., 2008; Dogru ve ark., 2011).

Chiang ve ark. (2009)' ları, otolog serum elde edilmesi mümkün olmayan hastalarda kalıcı epitel hasarlarının tedavisinde allojenik serum göz damlası kullanımı ile ilgili başarılı sonuçlar bildirmişlerdir.

Sonuç olarak otolog serum uygulaması uygun üretim ve tedavi protokolü ile standart kuru göz tedavi araçlarının yetersiz olduğu durumlarda etkinliği gösterilmiş güvenli bir tedavi metodu olarak karşımıza çıkmaktadır. 


\section{Plazma}

P1htı oluşturan fibrin gibi proteinler açısından serumdan daha zengin, ancak pıhtılaşma sırasında trombositlerden salınan büyüme faktörleri açısından daha fakirdir. Taze donmuş plazma kan bankalarında hazır şekilde bulunan bir üründür.

\section{Trombosit süspansiyonları-jelleri}

Serum ile karşılaştırıldığında büyüme faktör konsantrasyonu en yüksek olan üründür. Hücre proliferasyonu en iyi trombosit jeli ile desteklendiğini buna karşılık hücre farklılaşmasını en iyi serumun desteklediğini gösteren çalışmalar vardır (Hartwig ve ark., 2004; Liu ve ark., 2006).

\section{Albümin}

Gözyaşında en yüksek konsantrasyonda bulunan protein albümindir. Yapılan çalışmalarda yüzey boyanmasının belirgin olarak düzeldiği ve semptomlarda azalma olduğu saptanmıştır (Shimmura ve ark., 2003; Unterlauft ve ark., 2009). Serum albumini kalite kontrolleri yapılmıș bir ürün olarak üretildiğinden otolog seruma alternatif olabilcek bir yöntem olarak öne sürülmüştür (Unterlauft ve ark., 2009). Hayvan çalışmalarında epitel defektini iyileştirici etkisi özellikle $\% 10$ 'luk konsantrasyonlarda anlamlı bulunmuştur (Shimmura ve ark., 2003).

\section{Kordon kanı}

İyileşmeyen kalıcı epitel defektlerin tedavisinde yüksek oranda büyüme faktörü içeren kordon kanı kullanılmıştır ancak uygulama ve elde etme zorluğu açısından kısıtlı bir uygulama alanı söz konusudur (Yoon ve ark., 2007).

\section{Kuru göz hastalığında girișimsel yöntemler}

Medikal tedavi ile sonuç alınamayan olgularda cerrahi girişimler gerekebilir. Kuru göz olgularında başlıca girişimsel yöntemler punktum oklüzyonu, forniks rekonstrüksiyonu, kapak tamiri, ekspojur keratopati için kapak cerrahisi/tarsorafi, keratoplasti, limbal kök hücre nakli, amnion membran nakli ve keratoprotez gibi daha ileri yöntemlerdir. Cerrahi girişimler özetle şunlardır (Geerling ve ark., 2008).

\section{2.a. Lakrimal drenaj sistem tıkaçları}

T1kaçlar yapıldıkları materyale (silikon/ kollajen) veya yerleşim yerine göre (punktal, lakrimal ampulla, kanaliküler) sınıflandırılabilirler. Geçici tıkaçlar kollajen, jelatin, polidioksan, hidroksipropilmetilselüloz gibi emilen materyallerden, kalıcı tıkaçlar ise silikon, polimetakrilat polietilen ve N-butil siyanoakrilat gibi materyallerden üretilmişlerdir. En sık kullanılan kalıcı materyaller silikondan yapılmış Herrick ve akrilattan yapılmış tıkaçlardır. Tıkaç yerleştirilmesi sonrası proinflamatuar ajanlarda artış olabileceğinden özellikle oküler yüzeyde belirgin inflamasyonun olduğu olgularda öncesinde antiinflamatuar tedavi düzenlenmelidir. Kliniğimizden bir çalışmada tıkaç sonrası yüzey epiteli değişimleri impresyon sitolojisi ile incelenmiş ve belirgin olarak goblet hücre sayısı ve morfolojisinde değişim izlenmiştir (Dursun ve ark., 2003). Yapılan başka bir çalışmada silikon ve kollajen tıkaç sonrası lakrimal sintigrafi çekilmiş ve her iki tıkacın da gözyaşı miktarını belirgin olarak arttırdoğı izlenmiştir (Altan-Yaycioglu ve ark., 2005). Nadir görülen komplikasyonlardan biri de pyojenik granülom oluşumudur (Akova ve ark., 1999). 2.b. Lakrimal drenaj sisteminin cerrahi oklüzyonu

T1kaçların fayda sağladığı ancak gerek sık tıkaç kaybı gerekse tıkaca bağlı komplikasyonların geliştiği durumlarda cerrahi uygulanabilir.

\section{2.c. Konjonktiva cerrahisi}

Hem düzgün bir konjonktival yüzey elde etmek hem de konjonktival inflamasyonu azaltmak amaçlıdır. Özellikle sikatrisyel konjonktival hastalıklarda fibrotik doku uzaklaştırılır ve inflamasyon azaltılır. Konjonktivoşalazis, superior limbik keratokonjonktivit, pterjiyum, pinguekula, StevensJohnson Sendromu ve oküler sikatrisyel pemfigoid bu grup hastalıklardır.

\section{Sikatrisyel oküler yüzey hastalığı}

Steven Johnson, sikatrisyel pemfigoid, Lyell sendromu, rozasea, atopik keratokonjonktivit, sarkoidoz, trahom, sistemik skleroz bu grupta sayılabilir. Bu grup hastalıklarda konjonktivada kronik immunolojik inflamasyon vardır ve goblet hücreleri hasara uğramıştır. İnflame dokunun uzaklaştırılması bu hastalıkların ilerlemesini durdurmaya ve oküler yüzeyi stabilize etmeye yardımcı olabilir. Varsa trikiazis ve entropion için uygun cerrahi girişimler yapılmalıdır. Amnion membran örtülmesi, limbal kök hücre nakli gerekebilir (Shimmura ve ark., 2002). Oral mukozadan elde edilen hücrelerin nakli son yıllarda uygulanan yöntemlerdendir. Sistemik immunsupresyon özellikle bilateral şiddetli seyreden olgularda gerekebilir.

\section{2.d. Korneal ve limbal kök hücre cerrahisi Korneal cerrahi}

Kuru göze bağlı epitel defektlerinin iyileşme döneminde opasite kalabilir. Görme keskinliğini etkileyen durumlarda keratoplasti gerekebilir. Derin ön lameller keratoplasti (DALK) tercih edilebilir. Kuru göz olgularında greft rejeksiyon riski artmıştır, bu olgularda agresif tedavi yöntemleri uygulanmalıdır.

\section{Limbal kök hücre nakli}

Kuru göze yol açan etyolojik faktörler limbal yetmezliğe de yol açabilir. Kimyasal ve alkali yanıklar, Stevens Johnson Sendromu, oküler sikatrisyel pemfigoid gibi sikatrizan konjonktivitler bu grupta sayilabilir.

Kuru göz oküler inflamasyonu arttırır, inflamasyonun artması kuru gözü daha da kötüleştirir. İnflamasyonu bask1lammak için konjonktiva ve kapak cerrahisi uygulanmalıdır. Şiddetli oküler yüzey bozukluğu ile beraber limbal yetmezlik bulguları mevcutsa tek seçenek limbal kök hücre naklidir. Otogreft veya allogreft limbal kök hücre nakli yapılabilir. Limbal kök hücrelerin ex vivo üretilerek çoğaltılması bu alanda gelecek vaat eden en önemli konulardan biridir (Liang ve ark., 2008).

\section{2.e. Amnion membran nakli}

Dirençli epitel defektleri ve ülserasyonlar özellikle romatolojik hastalıklarda, greft-versus-host hastalığında ve nörotropik keratopatilerde sıktır. Medikal yöntemler başarısız olduğunda amnion membran nakli etkili yöntemlerden biridir. Amnion membran bazal membran olarak görev görür ve epitel hücrelerinin göçünü hızlandırır. Epitelyal farklılaşmayı destekler, kornea hassasiyeti ve gözyaşı film tabakasını güç- 
lendirir. Fibroblastlarca uyarılan TGF $\beta$ ve reseptör aktivasyonunu azaltır ve fibrozisi engeller. İnflamasyonu nasıl bask1ladığ1 yönünde değişik görüşler vardır, muhtemelen gözyaşı film tabakasına karşı bariyer oluşturarak inflamatuar hücrelerin mediatörlerinin azalmasına neden olmaktadır (Fernandes ve ark., 2005). Derin ve perfore noninfeksiyöz ülserlerde çok katlı amnion membranı stromal kalınlığı sağlar ve epitel iyileşmesi için gerekli büyüme faktörleri ve kollajenler için ortam sağlar (Ertan ve ark., 2002).

2.f. Keratoprotez cerrahisi

2.g. Lakrimal drenaj cerrahisi

2.h. Kapak cerrahisi

\section{2.i. Müköz membran cerrahisi}

Sembleferon, goblet hücreleri içeren konjonktivada azalma, entropion, trikiazis, gözyaşı film tabakasında bozulma ve yüzey bozukluğu ile giden bir durumdur. Bu olgularda müköz membran greftleri kullanılmaktadır (Henderson ve ark., 2008). Otolog greftler konjonktiva, tars, oral ve nazal mukoza; heterolog greft ise amnion zarıdır. Bu greftler aynı zamanda gözyaşının müköz komponentini desteklemek amacı ile de kullanılırlar.

\section{2.j. Küçük tükrük bezi nakli}

Aşırı kuru göz olgularında, medikal tedaviye yanıtsı, görme kaybı gelişen olgularda tedavi seçeneği olabilir (Geerling ve ark., 2008). Tükrük gözyaşındakine benzer şekilde büyüme faktörleri, albumin, immunoglobulinler içerir. Yeni bir tedavi seçeneği olarak gündeme gelmiştir, ancak tecrübeler henüz daha kısıtlı olduğu için uzun süre takipli çalışmalara ihtiyaç vardır.

\section{2.k. Büyük tükrük bezi nakli}

Parotis, sublingual ve submandibuler bezler şiddetli kuru göz olgularında kullanılabilen büyük tükrük bezleridir. Nakil öncesi mutlaka Sjögren hastalığı gibi tükrük bezi hastalıkları ve inflamatuar hastalıklar ekarte edilmelidir. En uygun olanı submandibuler bez transplantasyonu olarak gözükmektedir ve sonuçları daha iyidir (Geerling ve ark., 2008). Otolog submandibuler bez nakli ilk defa Murube-del-Castillo tarafindan 1986'da yapılmıştır (Sieg ve ark., 2000). Submandibuler bez temporal fossaya temporal kas içine, kanalı ise üst lateral konjonktiva forniksine implante edilir.

\section{Geleceğe yönelik tedavi yaklaşımları}

Ciddi olgularda sık suni gözyaşı damla uygulama gereksinimi nedeniyle viskozitesi daha yüksek, göz yüzeyinde daha uzun süre kalarak koruyucu özelliği yüksek ve iyileştirmeyi hızlandırıcı ajanlar geliştirilmektedir. Bu amaçla sodyum hyalüronat içeren preparatlar kullanıma sunulmuştur. Yapılan bir çalışmada $\% 0,1$ ve \%0,2 konsantrasyondaki sodyum hyalüronat damlaları ile klinik iyileşme açısından benzer sonuçlar rastlanmıştır (Karalezli ve ark., 2010).

Diğer bir tedavi yöntemi alt fornikse yerleştirilen ve tüm gün yavaşça absorbe edilen hidroksipropil selüloz oftalmik insert (Lacrisert)'dir (Wander ve ark., 2009).

Sonuç olarak yayınlarda özellikle suni gözyaşı preparatlarını uzun süre kullanmayı tolere edemeyen hastalarda güvenilir, tolere edilebilen etkili bir yöntem olarak bildirilmiştir (Nguyen ve ark., 2011). Ancak bu insertler halen ülkemizde bulunmamaktadır.

\section{Nutrisyonel tedavi}

Keten tohumu yağının, omega 3 yağ asitlerinin, n-6 ve n-3 poliansatüre yağ asitlerinin kuru göz bulgularını azalttığ yönünde çalışmalar mevcuttur (Barabino ve ark., 2003; Pinhero ve ark., 2007; Viau ve ark., 2009). Omega-3 yağ asitlerinden zayıf ya da omega-6'nın oranının fazla olduğu diyetler, düşük vitamin A alımı kuru göz sendromunu arttırabilir. Keten tohumu yağının etkisi araştırılmış, kuru göz testlerinde düzelmenin yanısıra oküler inflamasyonu da baskıladığı gösterilmiştir (Pinhero ve ark., 2007).

\section{Mukolitikler ve sekretegoglar}

Yüzde 5-20 N-asetilsistein konsantrasyonları (Brunac), müsinin disülfit çapraz bağlarını kırarak fazla müsini eritir. Sekretegoglar, muskarinik asetilkolin reseptör aganistleri, pilokarpin (Salagen) ve cevimeline (Evoxac) mevcut preparatlardır. Ağız kuruluğu gibi kolinerjik yan etkileri vardır.

\section{Topikal vitamin A preparatları}

Epitel iyileşmesini hızlandıran ve goblet hücrelerinin müsin üretimini arttıran preparatlardır. Ülkemizde de preparatı mevcuttur. Matriks metalloproteinaz aktivitesi kuru göz hastalarında yüksek bulunmuştur. Matriks metalloproteinazı inhibe ederek etki gösteren antibakteriyel olmayan doksisiklinin yeni formülasyonunun etkinliği ile ilgili çalışmalar devam etmektedir. Bir hayvan çalışmasında lipozoma-bağlı tetrasiklinin kuru göz üzerindeki etkisi araştırılmış, her iki ajanın kombinasyonu kuru göz bulgularında belirgin derecede düzelme sağlamıştır (Shafaa ve ark., 2011).

\section{Üzerinde çalışılan ajanlar}

Diquafasol tetrasodyum (INS365): Purinerjik reseptör (P2Y2) agonistidir. Bu ajan yüzey hücrelerini direkt olarak uyararak sıvı ve müsin sekresyonunu ve aynı zamanda meibomian glandlardan lipid sekresyonunu arttırmaktadır.

Eikozanoid: 15-(S)-HETE derivesi olarak geliştirilmiştir. MUC1 sekresyonunu arttırmaktadır. Topikal 15-(S)-HETE, oküler yüzey müsin eksikliği olgularında yararlı olabilir. Yapılan plasebo kontrollü bir çalışmada anlamlı bir etkinliği gösterilememiştir.

Ecabet: Ecabet sodyum, konjonktival goblet hücrelerinden müsin üretimini arttıran bir ajandır. Bu ajan Japonya'da gastrik ülserlerde kullanılmaktadır.

Takrolimus (FK-506): Potent bir immunosupresif ajan olan takrolimus bazı ülkelerde atopik dermatitde pomad olarak kullanılmaktadır. Ancak oftalmik kullanım için onay alınmamış bir ajandır. Çalışmalar devam etmektedir.

Androjenler: Androjenler, epitel hücre morfolojisi, gen ekspresyonu, protein sentezi, sekretuar olayları ve immün fonksiyonları düzenlerler. Androjen eksikliği menapoz sırasında, yaşlanma ve bazı otoimmün hastalıklarda aköz yetmezliği ve evaporatif kuru gözü olan olgularda etyopatogenezde rol almaktadır. Topikal androjen damlaların kullanımı gündeme gelmiştir. Androjenin meibomian bez salgısını arttırması özellikle evaporatif tip kuru göz tedavisinde umut vericidir. Topikal formdaki testesteron damlanın faz 3 çalışmaları devam etmektedir.

\section{Sonuç}

Sonuç olarak etyopatogenezin daha iyi anlaşılması ile hedefe yönelik tedavi ajanları geliştirilmektedir. Halen çalış1- 
makta olan ajanlar düşünüldüğüde gelecekte belki de oldukça etkili tedavi metodları ile kuru göz hastalarını tedavi edilebi- leceği umulmaktadır.

\section{KAYNAKLAR}

Akova, Y.A., Demirhan, B., Çakmakçı, Ş., Aydin, P., 1999. Pyogenic granuloma: a rare complication of silicone punctal plugs. Ophthalmic Surg. Lasers. 30, 584-585.

Akova, Y.A., Akça, S., 2008. Keratokonjonktivitis Sikka. Türkiye Klinikleri. J. Ophthalmol. Special Topics. 1, 119-126.

Altan-Yaycioglu, R., Gencoglu, E.A., Akova, Y.A., Dursun, D., Cengiz, F., Akman , A., 2005. Silicone versus collagen plugs for treating dry eye: Results of a prospective randomized trial including lacrimal scintigraphy. Am. J. Ophthalmol. 140, 88-93.

Altinors, D.D., Akca, S., Akova, Y., Bilezikci, B., Goto, E., Dogru, M., Tsubota, K., 2006. Smoking associated with damage to the lipid layer of the ocular surface. Am. J. Ophthalmol. 141, 1016-1021.

Barabino, S., Rolando, M., Camicione, P., Ravera, G., Zanardi, S., Giuffrida, S., Calabria, G., 2003. Systemic linoleic and gamma-linoleic acid therapy in dry eye syndrome with an inflammatory component. Cornea. 22, 97-101.

Behrens, A., Doyle, J.J., Stern, L., Chuck, R.S., McDonnell, P.J., Azar, D.T., Dua, H.S., Hom, M., Karpecki, P.M., Laibson, P.R., Lemp, M.A., Meisler, D.M., Del Castillo, J.M., O'Brien, T.P., Pflugfelder, S.C., Rolando, M., Schein, O.D., Seitz, B., Tseng, S.C., Van Setten, G., Wilson, S.E., Yiu, S.C., 2006. Dysfunctional tear syndrome: A Delphi approach to treatment recommendations. Cornea. 25, 900-907.

Chiang, C.C., Chen, W.L., Lin, J.M., Tsai, Y.Y., 2009. Allogeneic serum eye drops for the treatment of persistent corneal epithelial defect. Eye (Lond). 23, 290-293.

Craig, J.P., Tomlinson, A., 1997. Importance of the lipid layer in human tear film stability and evaporation. Optom. Vis. Sci. 74, 8-13.

Djalilian, A.R., Hamrah, P., Pflugfelder, S.C., 2005. Dry eye. In: Krachmer JH, Mannis MJ, Holland EJ. Cornea: Fundamentals, diagnosis, and management. 2nd ed. Elsevier, Mosby; Philadelphia. 521-540.

De Paiva, C.S., Corrales, R.M., Villarreal, A.L, Farley, W.J., Li, D.Q., Stern, M.E., Pflugfelder, S.C., 2006. Corticosteroid and doxycycline supress MMP-9 and inflammatory cytokine expression, MAPK activation in the corneal epithelium in experimental dry eye. Exp. Eye Res. $83,526-535$.

Dogru, M., Tsuboto, K., 2011. Pharmacotherapy of dry eye. Expert. Opin. Pharmacoter. 12, 325-334.

Dursun, D., Ertan, A., Bilezikçi, B., Akova, Y.A., Pelit, A., 2003. Ocular surface changes in keratoconjunctivitis sicca with silicone punctum plug occlusion. Curr. Eye Res. 26, 263-269.

Ertan, A., Akova, Y.A., Aydın, P., 2002. Oküler yüzey bozukluğu tedavisinde amniotik membran transplantasyonu. Türk Oftalmoloji Gazetesi. 32, 902-908.

Fernandes, M., Sridhar, M.S., Sangwan, V.S., Rao, G.N., 2005. Amniotic membrane transplantation for ocular surface reconstruction. Cornea. 24, 643-653.

Frucht-Pery, J., Chayet, A.S., Feldman, S.T., Lin, S., Brown, S.I., 1989. The effect of doxycycline on ocular rosasea. Am. J. Ophthalmol. 107, 434-435.

Fox, R.I., Chan, R., Michelson, J.B., Belmont, J.B., Michelson, P.E., 1984. Beneficial effect of artificial tears made with autologous serum in patients with keratoconjunctivitis sicca. Arthritis Reum. 27, 459-461.

Geerling, G., Hartwig, D., 2006.Autologous serum eyedrops for ocular surface disorders. In: Reinhard T, Larkin LFP, eds. Cornea and External Eye Disease. Berlin: Sğringer-Verlag. 2-20.

Geerling, G., Brewitt, H., 2008. Flow chart on surgical approaches to dry eye. Dev. Ophthalmol. 41, 313-316.

Geerling, G., Raus, P., Murube, J., 2008. Minor salivary gland transplantation. Dev. Ophthalmol. 41, 243-254.

Geerling, G., Sieg, P., 2008. Transplantation of the major salivary glands. Dev. Ophthalmol. 41, 255-268.

Geerling, G., Unterlauft, J.D., Kasper, K., Schrader, S., Opitz, A., Hartwig, D., 2008. Autologous serum and alternative blood products for the teratment of ocular surface disorders. Ophthalmologe. 105, 623-631.

Hartwig, D., Hrloff, S., Liu, L., Schlenke, P., Wedel, T., Geerling, G., 2004. Epitheliotropic capacity of a growth factor preparation produced from platellet concentrates on corneal epithelial cells: A potential agent for the treatment of ocular surface defects? Transfusion. 44, 17241731.

Henderson, H.W., Collin, J.R., 2008. Mucous membrane grafting. Dev. Ophthalmol. 41, 230-242.

Herminghaus, P., Geerling, G., Hartwig, D., Wedel, T., Dibbelt, L., 2004. Epitheliotropic capacity of serum and plasma eye drops. Influence and centrifugation. Ophthalmologe. 101, 998-1005.

Karalezli, A., Borazan, M., Kucukerdonmez, C., Akova, Y.A., 2010. Farklı konsantrasyonlardaki sodyum hyalüronat göz damlalarının kuru göz tedavisindeki etkinliklerinin karşılaştırılması. T. Klinikleri. J. Ophthalmol. 19, 78-83.

Lee, G.A., Chen, S.X., 2010. Autologous serum in the management of recalcitrant dry eye syndrome. Clin, Exp. Ophthalmol. 36, 119-122.

Liu, L., Hartwig, D., Harloff, S., Herminghaus, P., Wedel, T., Geerling, G., 2005. An optimised protocol for the production of autolgous serum ayedrops. Graefes Arch. Clin. Exp. Ophthalmol. 243, 706-714.

Liu, L., Hartwig, D., Harloff, S., Herminghaus, P., Wedel, T., Kasper, K., Geerling, G., 2006. Corneal epitheliotropic capacity of three different blood-derived preparations. Invest. Ophthalmol. Vis. Sci. 47, 2438-2444.

Liang, L., Sheha, H., Li, J., Tseng, S.C., 2009. Limbal stem cell transplantation: new progresses and chalenges. Eye (London). 23, $1946-1953$.

Murube, J., Paterson, A., Murube, E., 1998. Classification of artificial tears. II: Additives and commercial formulas. Adv. Exp. Med. Biol. 438, 705-715.

Nguyen, T., Latkany, R., 2011. Review of hydroxypropyl cellulose ophthalmic inserts for treatment of dry eye. Clin. Ophthalmol. 5, 587-591.

Perry, H.D., Doshi-Carnavale, S., Donnendfeld, E.D., Solomon, R., Biser, S.A., Bloom, A.H., 2006. Efficacy of commercially avaliable topical Cyclosporine A $0.05 \%$ in the treatment of meibomian gland dysfunction. Cornea. 25, 171-175.

Pflugfelder, S.C., De Paiva, C.S., Villarreal, A.L., Stern, M.E., 2008. Effects of sequential artificial tear and cyclosporine emulsion therapy on conjunctival goblet cell density and transforming growth factor- $\beta 2$ production. Cornea. 27, 64-69.

Pflugfelder, S.C., Jones, D., Ji, Z., Afonso, A., Monroy, D., 1999. Altered cytokine balance in the tear fluid and conjunctiva of patients with Sjogren's syndrome keratoconjunctivitis sicca. Curr. Eye Res. 19, 201-211.

Pinhero, M.N.J., dos Santos, P.M., dos Santos, R.C., Barros, J.N., Passos, L.F., Cardoso Neto, J., 2007. Oral flaxseed oil (Linum usitatissimum) in the treatment for dry-eye Sjögren's syndrome patients. Arq. Bras. Oftalmol. 70, 649-655.

Sall, K., Stevensen, O.D., Mundorf, T.K., Reis, B.L., 2000. Two multicenter, randomized studies of the efficacy and safety of cyclosporine ophthalmic emulsion in moderate to severe dry eye disease. Ophthalmology. 107, 631-639.

Shafaa, M.D., El Shazly, L.H., El Shazly, A.H., El Gohary, A.A., El Hossary, G.G., 2011. Efficacy of topically applied liposom-bound tetracycline in the treatment of dry eye model. Veterinary Ophthalmol. 14, 18-25.

Sheedy, J.E., Shaw-McMinn, P.G., 2003. Computer vision syndrome. In: Diagnosis and treating computer related problems. Eds: Sheedy and 
Shaw-McMinn. Butterworth-Heinemann Burlington. p.p. 1-7.

Shimmura, S., Tsubota, K., 2002. Ocular surface reconstruction update. Curr. Opin. Ophthalmol. 13, 213-219.

Shimmura, S., Ueno, R., Matsumo, Y., Goto, E., Higuchi, A., Shimazaki, J., Tsubota, K., 2003. Albumin as a tear supplement in the treatment of dry eye syndrome. Br. J. Ophthalmol. 87, 1279-1283.

Sieg, P., Geerling, G., Kosmehl, H., Lauer, I., Warnecke, K., Von Domarus, H., 2000. Microvascular submandibular gland transfer for severe cases of keratoconjunctivitis sicca. Plast. Reconstr. Surg. 106, 554-562.

Stern, M.E., Beurma, R.W., Fox, R.I., Gao, J., Mircheff, A.K., Pflugfelder, S.C., 1998. The pathology of dry eye: The interaction between the ocular surface and the lacrimal glands. Cornea. 17, 584-589.

Stern, M.E., Gao, J., Siemasko, K.F., Beuerman, R.W., Pflufelder, S.C., 2004. The role of the lacrimal functional unit in the pathophysology of dry eye. Exp. Eye Res. 78, 409-416.

Stevenson, D., Tauber, J., Reis, B.L., 2000. The cyclosporin A Phase 2 Study Group Efficacy and Safety of Cyclosporin A ophthalmic Emulsion in the Treatment of Moderate-to-severe Dry Eye Disease A Dose-Ranging, Randomized Trial Ophthalmology. 107, 967-974.

Strong, B., Farley, W., Stern, M.E., Pflugfelder, S.C., 2005. Topical cyclosporine inhibits conjunctival epithelial apoptosis in experimental murine keratoconjunctivitis sicca. Cornea. 24, 80-85.

Tananuvat, N., Daniell, M., Sullivan, L.J., Yi, Q., McKelvie, P., McCarty, D.J., Taylor, H.R., 2001. Controlled study of the use of autologous serum in dry eye patients. Cornea. 20, 802-806.

Tsubota, K., Goto, E., Fujita, H., Ono, M., Inoue, H., Saito, I., Shimmura, S., 1999. Treatment of dry eye by autologous serum application in Sjogren's Sndrome. Br. J. Ophthalmol. 83, 390-395.

Unterlauft, J.D., Kohlhaas, M., Hofbauer, I., Kasper, K., Geerling, G., 2009. Albumin eye drops for treatment of ocular surface diseases. Ophthalmologe. 106, 932-937.

Utine, C.A., Akpek, E., 2010. Oftalmoloji literatüründe otolog serum göz damlası kullanımı: Genişleyen endikasyonlar. Türkiye Klinikleri. J. Ophthalmol. 19, 161-170.

Viau, S., Maire, M.A., Pasquis, B., Grégoire, S., Acar, N., Bron, A.M., Bretillon, L., Creuzot-Garcher, C.P., Joffre C., 2009. Efficacy of a 2-month dietary supplementation with polyunsaturated fatty acids in dry eye induced by scopolamine in rat model. Graef. Arch. Clin. Ophthalmol. 247, 1039-1050.

Wander, A.H., Koffler, B.H., 2009. Extending the duration on of tear film protection in dry eye syndrome: review and retrospective case series study of the hydroxypropyl cellulose ophthalmic insert. Ocular Surf. 7, 154-162.

Watson, S.L., Daniels, J.T., Geerling, G., Dart, J.K., 2010. Clinical trials of therapeutic ocular surface medium for moderate to severe dry eye. Cornea. 29, 1241-1246.

Wilson, S.E., Stulting, R.D., 2007. Agreement of physician treatment practices with the international task force guidelines for diagnosis and treatment of dry eye disease. Cornea. 26, 284-289.

Yağcı, A., 2010. Kuru Göz Hastalığı: “Güncel Gelişmeler Işı̆̆ında”. Kan ürünü gözyaşı takviyeleri. Basım: Güneş Tıp Kitabevleri. P.p. 91-97.

Yoo, S.E., Lee, D.C., Chang, M.H., 2005. The effect of low-dose doxycycline therapy in chronic meibomian gland dysfunction. Korean J. Ophthalmol. 19, 258-263.

Yoon, K.C., You, I.C., Im, S.K., Jeong, T.S., Park, Y.G., Choi, J., 2007. Application of umbilical cord serum eyedrops for the treatment of neurotrophic keratitis. Ophthalmol. 114, 1637-1642. 